\title{
Sources and deposition of organic matter in Cretaceous passive margin deep-sea sediments: a synthesis of organic geochemical studies from Deep Sea Drilling Project Site C03, outer Hatteras Rise
}

\author{
Philip A. Meyers \\ Marine Geology and Geochemistry Program, Department of Geological Sciences, The \\ University of Michigan, Ann Arbor, MI 48109-1063, USA
}

Received 11 July 1988; accepted 10 October 1988

\begin{abstract}
The results of organic geochemical studies of rock samples from Cretaceous strata at Site 603 on the outer Hatteras Rise are reviewed and integrated with their lithostratigraphic information. Although most of the strata contain little organic carbon, black shales enriched in organic matter were found in two settings. These rocks exist as claystones in the Aptian to Turonian Hatteras Formation and as marlstones in the Neocomian Blake-Bahama Formation. Terrigenous organic matter predominates in these deposits, except in Cenomanian and Valanginian rocks, where marine material becomes dominant. Organic carbon concentrations in Cenomanian black claystones are higher than any previously reported from the western North Atlantic, but lower than the concentrations found in the eastern North Atlantic. Black shales at Site 603 appear to result from downslope transport and rapid reburial of coastal and ocean margin sediments by turbidity flows. Deep-basin anoxia is not a major factor, except during the CenomanianTuronian, when the entire Atlantic Ocean may have briefly become anoxic. Organic matter in the sediments from all locations is thermally immature.
\end{abstract}

Keywords: black shales; organic matter; DSDP Site 603

\section{Introduction}

D/V Glomar Challenger occupied Site 603 on the North American outer continental rise during May and June, 1983, as part of Deep Sea Drilling Project (DSDP) Leg 93. The principal objectives of this leg were to drill a deep hole through sediments at the foot of the continental rise and to sample Jurassic basement. Recovery of the complete sedimentary record dating from the initial opening of the North Atlantic Ocean to the present was planned. The record actually obtained spans late Berriasian to early Pleistocene times and does not include the earliest part of this ocean's history owing to drillstring failure before basement was reached. The organic matter contents of the rocks encountered at Site 603 were examined in both shipboard and shore-based laboratories as part of the investigation of the sedimentary record.

A variety of processes influence the organic matter content of marine sediments. Concentrations are effected by the rates of supply of land-derived and marine matter, the rate of sediment accumulation, and the rate of post-depositional degradation of organic substances. The character of organic matter reflects biotic sources, transport routes, degree of preservation, and extent of geothermal alteration. Study of the organic matter present in older sediments can thus provide information about such palaeoceanographic factors as former rates of marine productivity and of bottom water ventilation.

During DSDP Leg 93, a large number of samples were collected from Site 603 for post-cruise organic geochemical study. Selection of the samples was based upon the specific requirements of each laboratory, coordinated when possible with the needs of other groups. In this way, several types of analyses were performed on related samples and investigators were not limited to randomly selected samples for their studies. One of the goals of this overview of the studies of organic matter in Leg 93 samples is to integrate their results, especially those from samples that are closely spaced or are lithostratigraphically related.

Where data from a specific sample are presented, the DSDP conventional identification system is used. In brief, each sample is identified by drill hole, core number, core section and centimetres within the section. As an example, Sample 603B-32-1, 26-28 cm, is from Hole 603B (the third hole at drill site 603), core 32 (the thirty-second $9 \mathrm{~m}$ length of sediment penetration), section 1 (the top $1.5 \mathrm{~m}$ section of the core), and is the $2 \mathrm{~cm}$ interval located between 26 and $28 \mathrm{~cm}$ from the top of the section. 


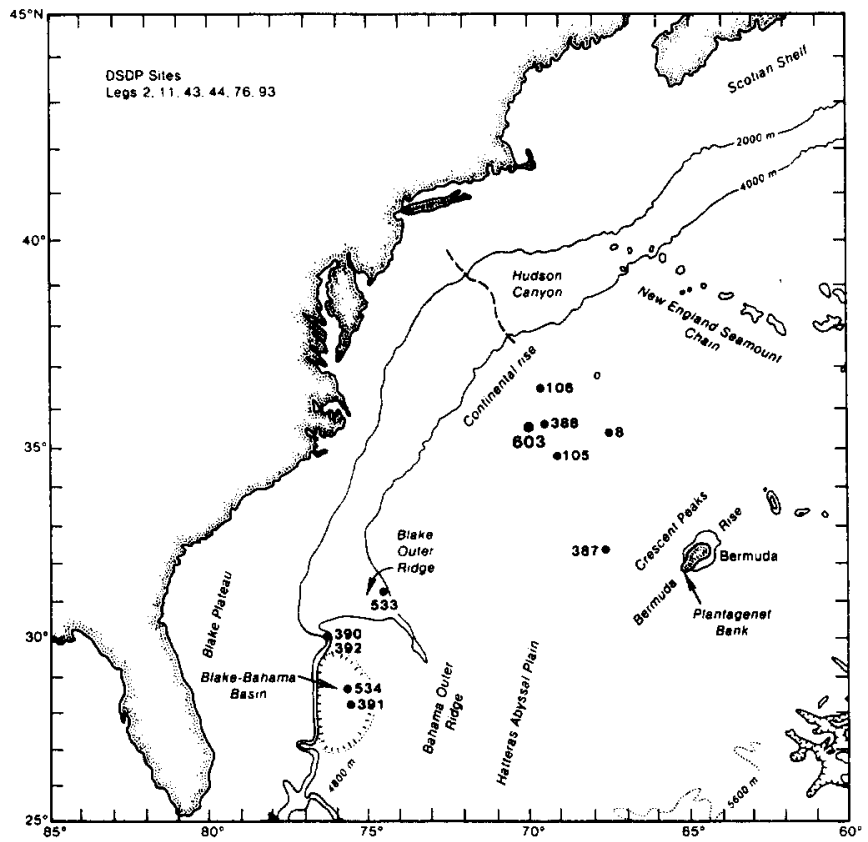

Figure 1 Locations of Site 603 and related DSDP sites in the western North Atlantic Ocean

\section{Site 603: outer Hatteras Rise}

Site 603 is located in $4434 \mathrm{~m}$ of water on the lower continental rise east of North Carolina (Figure 1). A nearly continuous record of sediment accumulation from Pleistocene to Berriasian times was recovered from the three holes cored by Leg 93, augmented by holes cored by Leg 95 at this site. The lithostratigraphic units encountered at Site 603 are shown in Figure 2 and are fully described by van Hinte et al. (1987). These units correspond to five of the six widespread Mesozoic-Cenozoic sedimentary formations identified in the western North Atlantic by Jansa et al. (1979). The sixth formation was probably present at Site 603 , but failure and resulting loss of the drill string terminated drilling before the entire sedimentary sequence had been penetrated. In Table 1, some of the results of organic geochemical analyses of samples from the five formations cored at Site 603 are summarized. However, this discussion will focus only on the three Cretaceous formations.

\section{Unit III: Plantagenet Formation (Turonian to Maastrichtian)}

Concentrations of organic carbon are generally very low throughout this claystone unit, as shown in Figure 3 which summarizes data from Meyers (1987). Rock Eval analysis of claystones poor in organic carbon give low hydrogeri index values, suggestive of microbially reworked, detrital continental organic matter (Herbin et al., 1987; Katz, 1987; Schaefer and Leythaeuser, 1987; Cunningham and Gilbert, unpublished data). Visual examinations of the organic matter content of these samples support this inference. Rullkötter et al. (1987) find $80 \%$ of the kerogen of a claystone sample to consist of recycled vitrinite. Habib and Drugg (1987) report the general dominance of micrinitic, terrigenous organic matter. Cunningham and Gilbert (unpublished data) determine that $80 \%$ of the kerogen in sample $603 \mathrm{~B}-29-1,121-126 \mathrm{~cm}$, a silty claystone having an organic carbon content of $1.68 \%$, is terrigenous in origin.

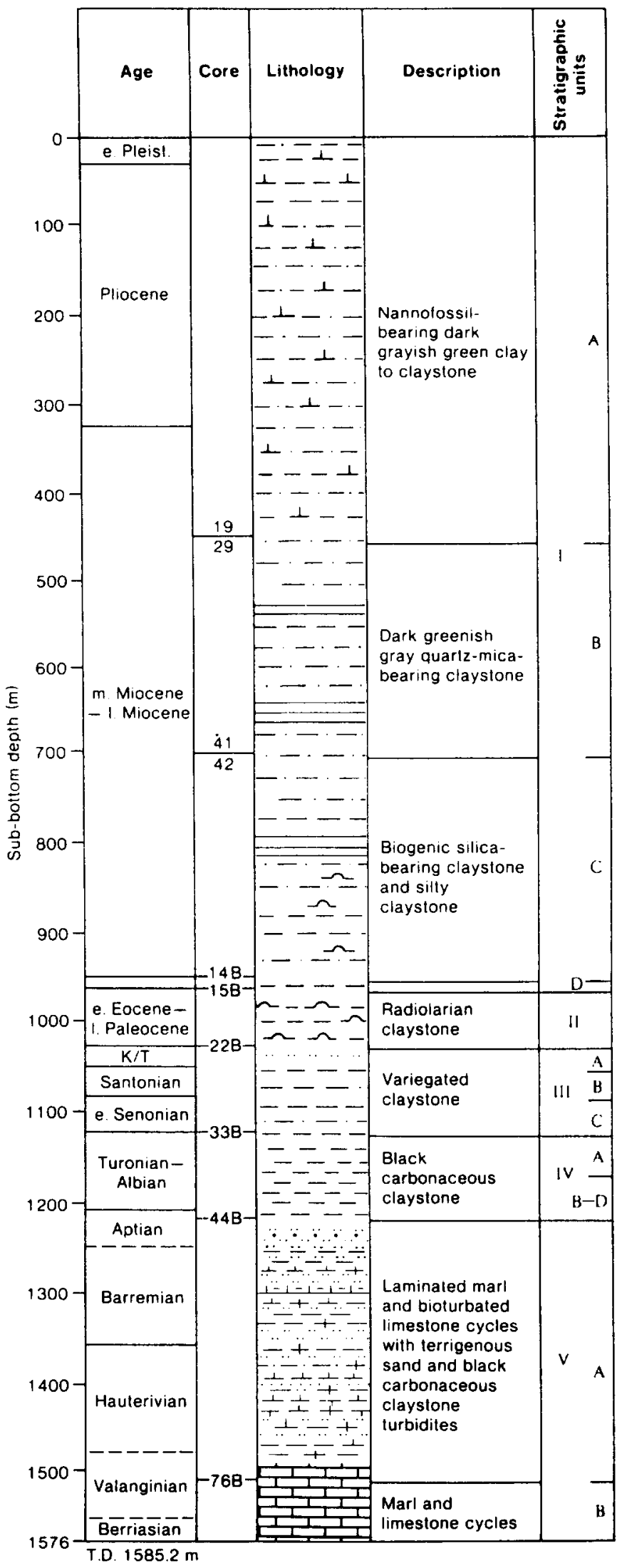

Figure 2 Stratigraphic summary of Site 603 on the outer Hatteras Rise. Stratigraphic units III, IV, and V correspond to the Plantagenet, Hatteras, and Blake-Bahama formations, respectively

In sample 603B-32-1, 26-28 cm, a black shale containing $8.48 \% \mathrm{C}_{\text {org }}$, Rullkötter et al. (1987) find a large proportion of marine n-alkanes in the total hydrocarbon composition. This sample has a hydrogen index of 346, characteristic of mixed type II/III organic 


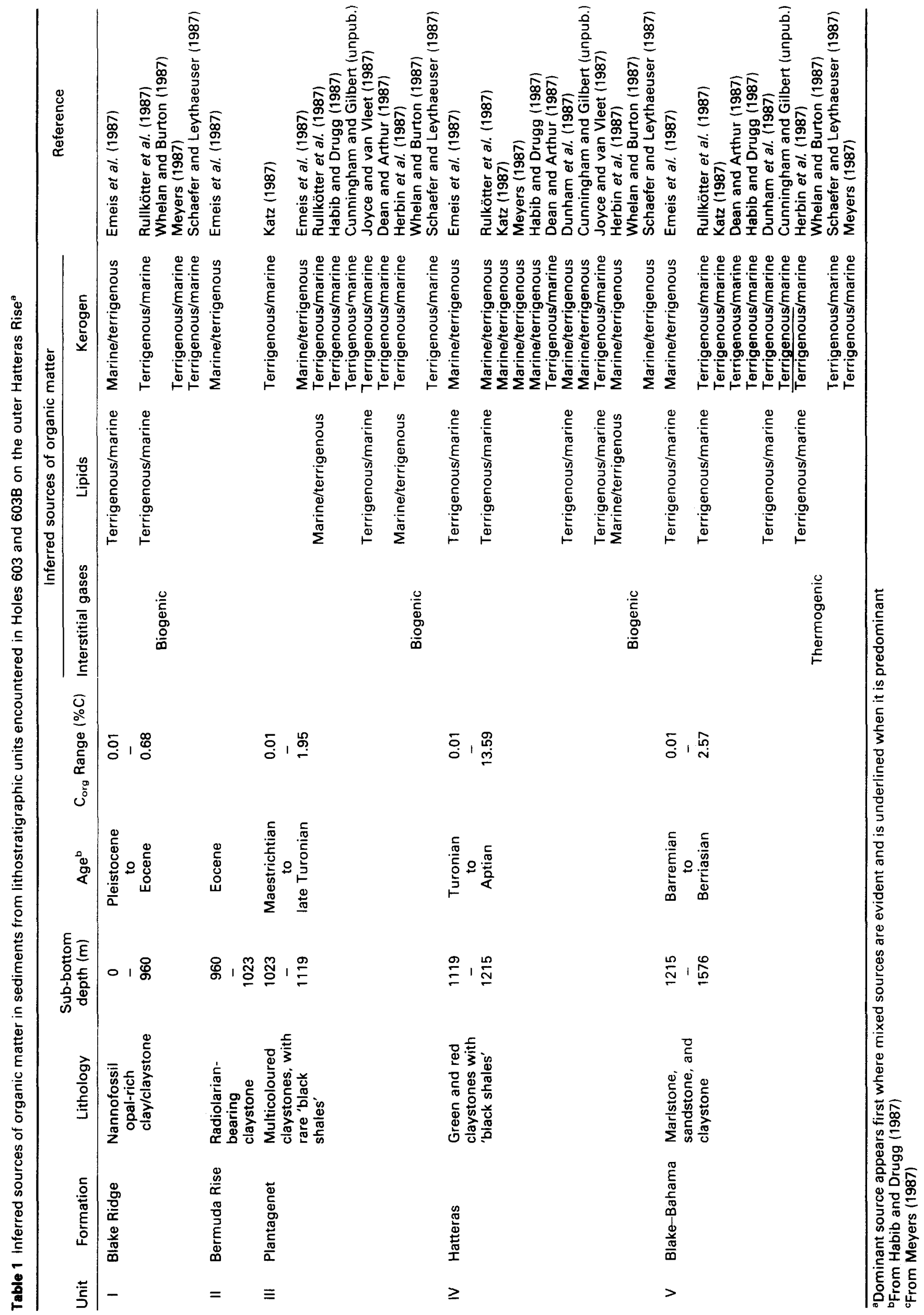




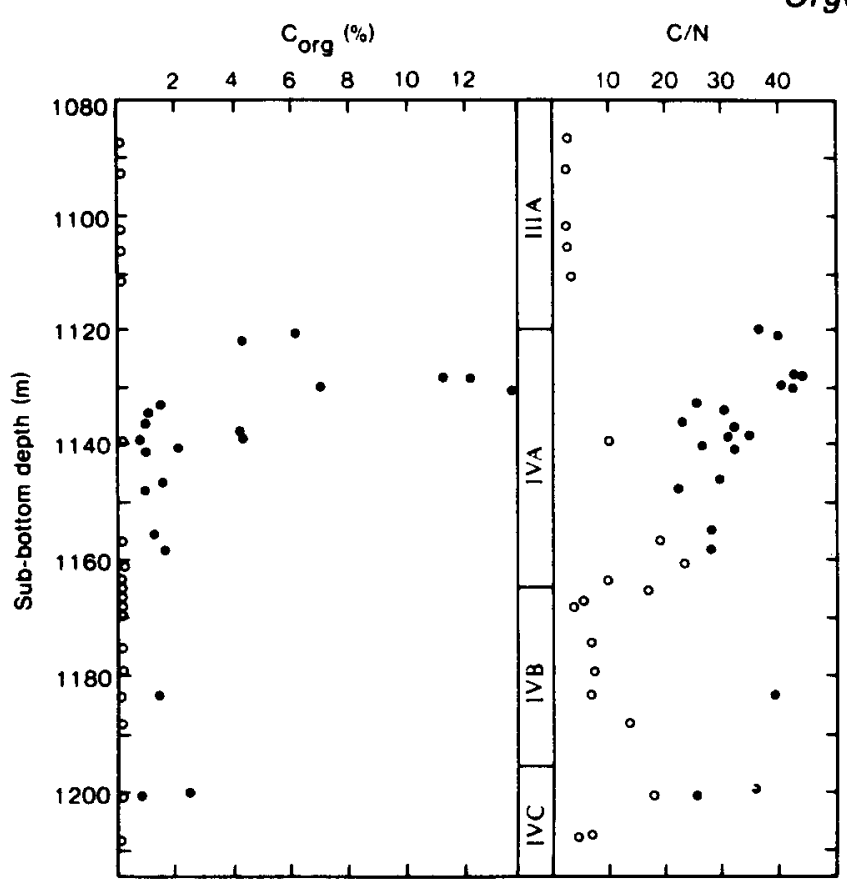

Figure 3 Concentrations of organic carbon and atomic carbon/nitrogen ratios in organic matter from samples from subunits IIIC, IVA, IVB, and IVC (Plantagenet and Hatteras formations) of Hole 603B. Solid circles represent black shales, and open circles represent red and green claystones. Data from Meyers (1987)

matter or partly oxidized type II marine material. A similar hydrocarbon distribution was found in sample 603B-29-1, 57-62 cm by Herbin et al. (1987), although this sample has a hydrogen index of only 34 . The variability in organic matter character in this unit is further shown by the dominance of land-plant n-alkanes in sample 603B-29-1, 48-53 cm (Joyce and van Vleet, 1987), which is not only closely situated to the other section 603B-29-1 sample, but also has nearly the same organic carbon content $(1.7 \%$ versus $1.8 \%)$. This variability is probably a result of the interlayering of turbiditic, hemipelagic, and pelagic sediments in this section (Wise and van Hinte, 1987), coupled with sporadic episodes of less than complete oxidation of sedimented organic matter.

\section{Unit IV: Hatteras Formation (Aptian to Turonian)}

This unit contains numerous black-coloured claystones. They are rich in organic carbon, with values ranging up to $20.4 \%$ by weight (Herbin et al., 1987). Highest organic carbon values are concentrated in Cenomanian claystones, and these are significantly higher than most previously reported values from the Hatteras Formation (cf. Erdman and Schorno, 1978; Deroo et al., 1980; Summerhayes and Masran, 1983), which have $10.4 \%$ as a maximum. These relatively high percentages contrast with those of adjacent green and red claystones, which are uniformly low as represented in Figure 3.

Atomic $\mathrm{C} / \mathrm{N}$ ratios of the black claystones average 33 whereas the values of interbedded organic-carbon-lean strata average $c$. 12 (Meyers, 1987). Similar contrasts in organic carbon contents and $\mathrm{C} / \mathrm{N}$ ratios have been observed in Cenomanian black shales and adjacent green claystones from DSDP Site $\mathbf{5 3 0}$ in the Angola Basin (Meyers et al., 1984). The contrast in $\mathrm{C} / \mathrm{N}$ values between black shales and green claystones may reflect matter in passive margin sediments: $P$. A. Meyers different amounts of diagenetic alteration of the original organic matter, different proportions of marine and continental organic matter in these two types of deposits, or some combination of these two possibilities. In modern surficial marine sediments, which are typically low in organic matter, $\mathrm{C} / \mathrm{N}$ values are commonly in the range of 9 to 18 (Stevenson and Cheng, 1972; Müller, 1977). These values deviate from those of marine plankton, which are the probable source of the bulk of the sediment organic matter and which usually have $\mathrm{C} / \mathrm{N}$ ratios between 4 and 8 (cf. Müller, 1977). This deviation indicates diagenetic losses of proteinaceous components of total organic matter at a rate greater than for other, more carbon-rich components, a process which modifies both the amount and the composition of organic matter during sinking to the sea bottom. Post-depositional diagenesis continues, but appears to degrade preferentially those components richer in carbon, with the result that $\mathrm{C} / \mathrm{N}$ ratios slowly become smaller with greater depth of burial (Müller, 1977; Waples and Sloan, 1980). It is equally plausible that the high organic carbon concentrations and the high $\mathrm{C} / \mathrm{N}$ values of the black claystones at Site 603 arise from enhanced preservation of carbon-rich components of organic matter, with loss of the more labile proteinaceous components, or from the addition of cellulose-rich land-derived plant matter to a background concentration of predominantly marine organic matter. $\mathrm{C} / \mathrm{N}$ values should not be used alone as geochemical palaeoceanographic indicators.

Rock Eval data from Unit IV samples show a wide

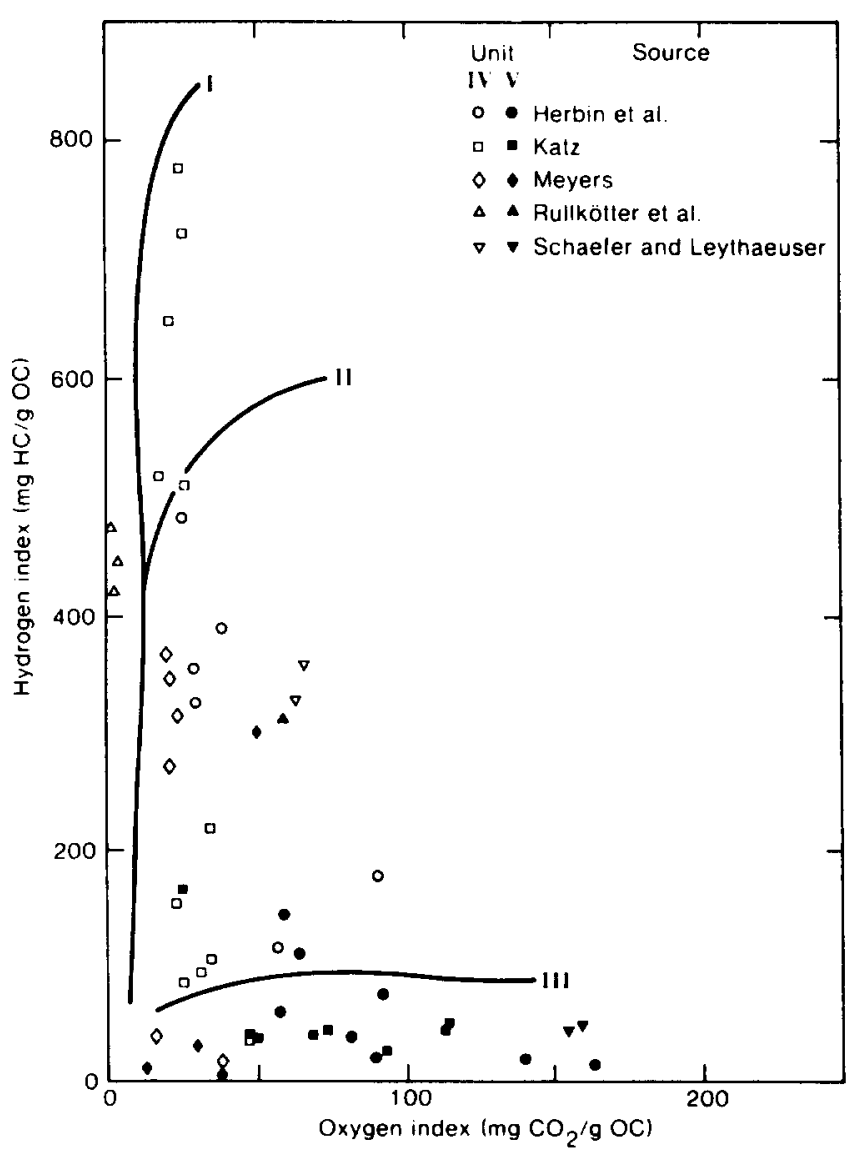

Figure 4 Summary of Rock Eval analyses of samples from Unit IV (Hatteras Formation) and Unit V (Blake-Bahama Formation) at Site 603. Hydrogen index is given in $\mathrm{mg}$ hydrocarbons per $\mathrm{g}$ organic carbon, and oxygen index is expressed as $\mathrm{mg} \mathrm{CO}_{2}$ per $\mathrm{g}$ organic carbon 


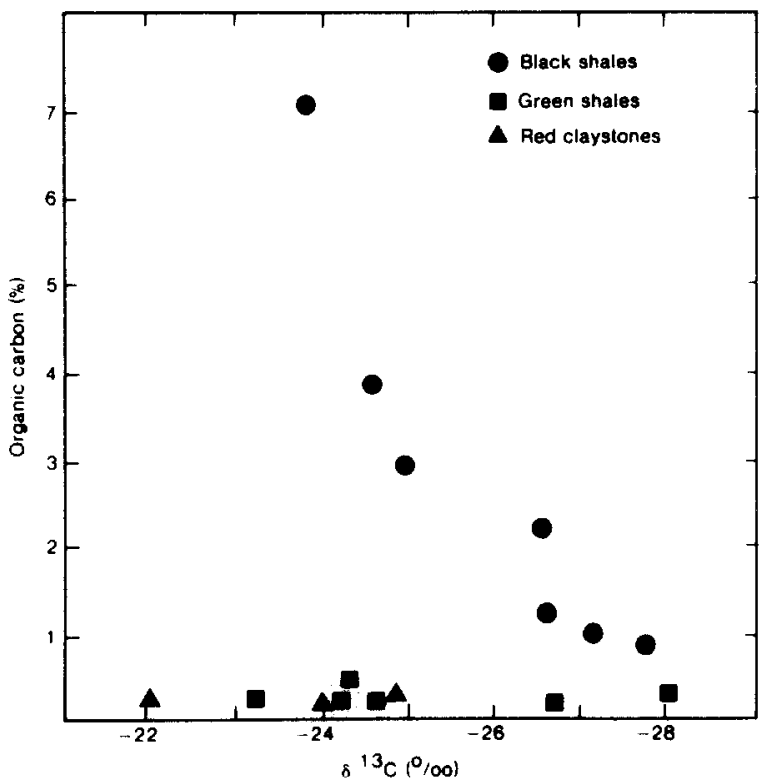

Figure 5 Organic carbon percentages versus carbon isotope values in samples from the Hatteras Formation, Hole 603B

range of hydrogen index values (Figure 4). The Cenomanian black shale samples from the Hatteras Formation generally have high hydrogen indices and low oxygen indices (Dean and Arthur, 1987; Herbin et al., 1987; Katz, 1987; Meyers, 1987; Rullkötter et al., 1987; Schaefer and Leythaeuser, 1987), representative of marine type II kerogen. Although most previous studies have concluded that the majority of the organic matter contained within western North Atlantic Cretaceous black shales is from continental sources, Summerhayes and Masran (1983) suggest that samples with higher organic carbon concentrations contain proportionately larger amounts of marine organic matter. Moreover, some Cenomanian sediments from site 105 are unusually rich in marine organic matter (Summerhayes, 1981) and Albian-Aptian sediments from sites 417 and 418 are dominated by marine material (Deroo et al., 1980). The abundance of marine organic matter in those Cenomanian sediments rich in organic carbon at hole $603 \mathrm{~B}$ evidently represents short episodes of enhanced preservation of marine material superimposed upon a low background of mixed marine and terrigenous organic matter. The mixed character of the organic-carbon-poor claystones is indicated by $\mathrm{C} / \mathrm{N}$ values higher than expected for purely marine matter (Figure 3) and hydrogen index (HI) and oxygen index (OI) values representative of oxidized marine organic matter combined with cellulosic continental material (Figure 4).

Carbon isotope ratios are reported for organic carbon contained within the black shales and adjacent strata of the Hatteras Formation. In Cenomanian black shales, Joyce and van Vleet (1987) and Dunham et al. (1987) find a generally positive correlation between organic carbon content and the heavier $\delta^{13} \mathrm{C}$ values typical of modern marine organic matter (e.g., Figure $5)$. The isotope signature in other examples of Cretaceous black shales is often reversed, however, with marine organic matter having $\delta^{13} \mathrm{C}$ values of -27 to $-29 \%$ and continental values being less depleted in ${ }^{13} \mathrm{C}$ (Meyers et al., 1984; Arthur et al., 1985; Dean et al., 1986). Carbon isotope analyses from a large suite of Hatteras Formation samples by Dean and Arthur
(1987) indicate that marine organic matter is indeed isotopically lighter than in modern sediments. In fact, the highest Rock Eval hydrogen indices, which are indicative of marine organic matter, are recorded in Cenomanian black shales that also are the isotopically lightest. Other black shales, as well as the green and red claystones, appear to contain lesser proportions of marine organic matter. Considerable variability in Rock Eval and isotope values from adjacent samples from this unit probably result from the changes in organic matter input and preservation associated with turbiditic deposition at this site.

In contrast to the predominantly marine character of kerogen in Unit IV black shales, the lipid materials are generally dominated by plant wax, terrigenous components. Both the extractable and bound fractions of n-alkanes, n-alkanoic acids, and n-alkanols contain major contributions of long-chain, biogenic components (Herbin et al., 1987; Emeis et al., 1987. Dunham et al., 1987; Joyce and van Vleet, 1987; Rullkötter et al., 1987). Lipid contents comprise a lower proportion of the total organic matter in black shales than in adjacent red or green claystones (Dunham et al., 1987), where land plant components are often minor. This difference in lipid richness is also inferred by Dean and Arthur (1987) from Rock Eval hydrogen indices and suggests that the organic matter in the black shales may have been redeposited from basin margin locations in an oxygenated, deep-basin site as a result of turbidity flow.

Exceptions to the general dominance of continental lipid components are found in upper Cenomanian black shales. In these deposits, from cores 603B-33 and 34 , hydrocarbon distributions indicate large proportions of marine lipid material (Herbin et al., 1987; Rullkötter et al., 1987). Pristane/phytane ratios less than one in these Cenomanian/Turonian samples lead Herbin et al. (1987) to suggest anoxic deposition, yet Dean and Arthur (1987) and Katz (1987) conclude that the sulphur contents of these samples are not high enough to indicate permanent bottom-water anoxia, and Bonnell and Anderson (1987) find that $\delta^{34} S$ values of disseminated pyrite are similar to those of modern oxic marine sediments. These findings do not, however, preclude short-lived periods of anoxia during the deposition of the Cenomanian/Turonian black shales.

Concentrations of $\mathrm{C}_{2}$ to $\mathrm{C}_{8}$ hydrocarbons are relatively low and reflect the thermal immaturity of the Hatteras Formation rocks at site 603 (Schaefer and Leythaeuser, 1987). From the dominance of methane over other light hydrocarbons, Whelan and Burton (1987) assign a biogenic origin to the interstitial gases. Low thermal maturity of the organic matter is further indicated by vitrinite data (Rullkötter et al., 1987; Emeis et al., 1987) and by visual kerogen descriptions (Cunningham and Gilbert, unpublished data; Habib and Drugg, 1987).

\section{Unit V: Blake-Bahama Formation (Berriasian to Barremian)}

The organic carbon contents of the various sedimentary types in Unit $\mathrm{V}$ do not differ greatly. The highest reported value is $3.14 \%$ (Dunham et al., 1987) for a black marlstone. The mean organic carbon concentration calculated from 33 such marlstones is $1.47 \%$ (Meyers, 1987). In comparison, the mean value 
for laminated limestones is $c .1 \%$ and for bioturbated limestones it is c. 0.2\% (Meyers, 1987; Dean and Arthur, 1987). Shipboard scientists observed that atomic $\mathrm{C} / \mathrm{N}$ ratios of organic matter increased in Blake-Bahama sediments at the same time that the amount of coaly particles became markedly greater, indicating inputs of continental plant debris in the submarine fan sequence at Site 603 .

As summarized in Figure 4, Rock Eval data show most of the organic matter in this unit to be type III oxidized or continental material (Katz, 1987; Dean and Arthur, 1987; Herbin et al., 1987; Schaefer and Leythaeuser, 1987). Several samples of turbiditic black marlstones, relatively rich in organic carbon, contained type II kerogen (Meyers, 1987), but such examples are not typical of this sequence. Relatively low $T_{\max }$ values in the range of 400 to $430^{\circ} \mathrm{C}$ show low thermal maturity in these sediments (Katz, 1987; Meyers, 1987; Dean and Arthur, 1987; Herbin et al., 1987; Schaefer and Leythaeuser, 1987), which agrees with visual maceral analyses (Rullkötter et al., 1987; Cunningham and Gilbert, unpublished data; Habib and Drugg, 1987) and low bitumen yields (Katz, 1987).

Like the organic carbon concentrations, the carbon isotopic compositions of organic matter are relatively uniform in Unit $\mathrm{V}$. The mean $\delta^{13} \mathrm{C}$ values of black shales, laminated limestones, and bioturbated limestones are $-25.3,-26.0$, and $-25 \%$, respectively (Dean and Arthur, 1987), and the isotopically light black shales found in the Hatteras Formation at this site are not present in the Neocomian sections obtained during Leg 93. Based upon $\mathrm{C} / \mathrm{N}$, Rock Eval, and carbon isotopic data, detrital land-derived material constitutes the bulk of the organic matter throughout Blake-Bahama sediments at Site 603, although components of algal cell walls continue to dominate the carbohydrate compositions of these sediments (Emeis et al., 1987).

Consistent with the largely terrigenous character of bulk organic matter, lipid distributions in black shales and limestones from the Blake-Bahama formation contain large contributions from land plant waxes (Herbin et al., 1987; Rullkötter et al., 1987; Emeis et al., 1987; Dunham et al., 1987). Non-aromatic hydrocarbon compositions are dominated by $\mathrm{C}_{27}, \mathrm{C}_{29}$, and $\mathrm{C}_{31} \mathrm{n}$-alkanes, with some samples having bimodal distributions in which $\mathrm{C}_{17}$ and $\mathrm{C}_{19}$ n-alkanes also appear prominantly. Pristane/phytane ratios in black shales are usually greater than one, suggesting oxygenated depositional conditions (Didyk et al., 1978) or limited methanogenic activity (Risatti et al., 1984).

Humic and vitrinitic organic matter is especially abundant in the Neocomian sediments obtained at Site 603 (Cunningham and Gilbert, unpublished data; Habib and Drugg, 1987; Rullkötter et al., 1987). Shipboard scientists commonly observed coaly particles in smear slides (van Hinte et al., 1987), which Habib and Drugg (1987) postulate may originate from in situ partial oxidation of buried land-derived plant debris. Rullkötter et al. (1987) report the existence of a relatively well preserved piece of humic coal containing framboidal pyrite in a Barremian sample. They conclude that short distance transport from a coastal swamp to this continental rise location and rapid reburial within a turbidite sequence is the most reasonable explanation for this interesting finding.

An exception to the general terrigenous origin of the organic matter content of Site 603 Blake-Bahama sediments occurs in Valanginian deposits in Subunit VB. Turbidites are uncommon in this subunit, and pelagic carbonates are the dominant lithologic type. Organic matter in this subunit appears to be mostly aquatic in origin, consisting largely of zooplankton fecal pellets, although it is structurally degraded and partially oxidized (Habib and Drugg, 1987; Rullkötter et al., 1987).

Analysis of $C_{2}$ to $C_{8}$ hydrocarbons suggests that some small scale migration of lighter components has occurred from black shale layers into organic-lean strata (Schaefer and Leythaeuser, 1987; Whelan and Burton, 1987). From distributions of these interstitial hydrocarbons, Whelan and Burton (1987) conclude they may be at least partially thermogenic in origin. Low concentrations of these light hydrocarbons, however, relect the general lack of thermal maturation of this section.

\section{Factors contributing to deposition of black shales at Site 603}

The proportion of continental and marine organic matter present in black shale samples from Site 603 and other western North Atlantic DSDP sites varies considerably. Although most of the organic matter appears to be terrigenous (Katz and Pheifer, 1982), the marine fraction increases with distance from North America (Tissot et al., 1980; Summerhayes and Masran, 1983). This pattern has been explained by Summerhayes and Masran (1983) to reflect the decrease in turbiditic dilution of marine sediments with continental materials as distance from shore increases. Exceptions to this generality occur where large proportions of marine organic matter are found in Cenomanian black shales at Site 105 (Summerhayes, 1981 ) and in Cenomanian and Valanginian black shales at Site 603 (Herbin et al., 1987; Meyers, 1987). Both sites are located close to each other on the continental rise (Figure 1) and in turbiditic environments. Such exceptions illustrate the regional and temporal variability that can exist in the mixture of organic matter types in black shales.

Preservation of organic matter is an important element in forming organic carbon-rich black shales. Anoxic bottom waters have been postulated to have enabled enhanced preservation of organic matter in the Cretaceous North Atlantic (Tissot et al., 1980; Arthur and Schlanger, 1979; Jenkyns, 1980; Summerhayes and Masran, 1983; Bralower and Thierstein, 1984; as examples). The abundant presence of burrowed, oxidized sediments above, below, and sometimes within the black shales in this ocean argue against such bottom water anoxia being extensive in either volume or duration (Katz and Pheifer, 1982; Waples, 1983). Nonetheless, the high concentrations of organic carbon found in Cenomanian black shales over most of the North Atlantic Ocean are compelling evidence in favour of periods of widespread bottom water anoxia (de Graciansky et al., 1984; Stein, 1986). As noted by Herbin et al. (1987), the Cenomanian-Turonian black shale sequence at Site 603 consists of 19 episodes of exceptional preservation of marine organic matter within a nine metre thickness of sediment. They propose short periods of bottom anoxia to achieve the observed alternations between black shales and green claystones. 
Another scenario leading to enhanced preservation of organic matter calls for the mid-water oxygen minimum zone to become intensified and perhaps expanded through sluggish circulation or enhanced influx of organic matter (for example, Demaison and Moore, 1980; Waples, 1983). Where a midwater anoxic layer intercepts the ocean bottom, sediments rich in organic matter can accumulate. Downslope movement of such sediments can result in formation of black shales within deep-ocean turbiditic sequences, as suggested by Dean et al. (1984) for Site 530 in the Angola Basin, if reburial is sufficiently rapid to preserve the organic matter. In view of the abundance of turbidites at Site 603 and the generally terrigenous character of organic matter in sediments from both the Hatteras and Blake-Bahama Formulations, Rullkötter et al. (1987), Habib and Drugg (1987), and Katz (1987) conclude that downslope displacement and rapid reburial by turbidity flows created most of the black shale deposits at this continental rise location.

\section{Summary and conclusions}

Cenozoic sediments contain low amounts of organic matter at Site 603 on the outer Hatteras Rise, reflecting accumulation in a well-oxygenated, bioturbated depositonal environment.

Aptian to Turonian sediments contain numerous, thin layers of dark-coloured claystones interspersed among red and green claystones within a generally turbiditic, bioturbated lithologic sequence. The black shales contain elevated concentrations of organic carbon, although not as high as found in similar deposits in the eastern North Atlantic, whereas the red and green claystones have virtually no organic matter within them.

Neocomian strata display many, thin, black marlstones deposited as turbidites within a sequence of pelagic bioturbated and laminated carbonates. Organic carbon concentrations of both the dark marlstones and the limestones are on the order of $1-2 \%$, which is less than values of the Turonian to Aptian black shales deposited below the calcite compensation depth.

Terrigenous organic matter dominates most sediments both enriched and lean in organic carbon at Site 603 on the outer continental rise. The major transport process from the North American continent was probably turbidity flow. The terrigenous organic matter is relatively lipid poor.

Marine organic matter is found in sediments deposited immediately prior to the CenomanianTuronian boundary and during Valanginian times. Concentrations of organic carbon reach $20 \%$ in Cenomanian black shales but are only a few percent in Valanginian marlstones. The dominance of marine organic matter may indicate enhanced aquatic productivity during these two intervals or it may record brief intervals of deep water anoxia which enhanced preservation of marine matter. Although deep basin anoxia would achieve better preservation, the abundance of oxidized sediment components and of faunal burrowing rules against widespread, long term anoxia in the western proto-Atlantic Ocean. A scenario of basin margin deposition within an oxygen-minimum zone and downslope transport and reburial by turbidity flows seems more likely to have formed most of the black shales at Site 603 .
Organic matter is thermally immature throughout these sections, although small amounts of low molecular weight hydrocarbons appear to have been generated from Neocomian black marlstones.

\section{Acknowledgements}

I thank the National Science Foundation for providing me the opportunity to participate in DSDP Leg 93, and Robert Cunningham for allowing me to use his unpublished kerogen results.

\section{References}

Arthur M. A. and Schlanger, S. O. (1979) Cretaceous 'oceanic anoxic events' as casual factors in development of reef reservoired giant oil fields AAPG Bull: 63, 870-885

Arthur, M. A., Dean, W. A., and Claypool, G. E. (1985) Anomolous ${ }^{13} \mathrm{C}$ enrichment in modern marine organic carbon Nature, 35, 216-218

Bonnell, L. M., and Anderson, T. F. (1987) Sulfur isotopic variations in nodular and disseminated pyrite: Hole 603B, In: Initial Reports. DSDP, Vol. 93 (Eds J. E. van Hinte, S. W. Wise $\mathrm{Jr}$, et al.) US Govt. Printing Office, Washington, DC, 1257-1262

Bralower, T. J. and Thierstein, H. R. (1984) Low productivity and slow deep-water circulation in mid-Cretaceous oceans Geology 12, 614-618

Dean, W. E. and Arthur, M. A. (1987) Inorganic and organic geochemistry of Eocene to Cretaceous strata recovered from the lower continental rise, North American Basin, Site 603 Deep Sea Drilling Project Leg 93, in: Initial Reports DSDP Vol. 93 (Eds J. E. van Hinte, S. W. Wise Jr, et al.) US Govt Printing Office, Washington, DC, p 1093-1137

Dean, W. E., Arthur, M. A. and Stow, D. A. V. (1984) Origin and geochemistry of Cretaceous deep-sea black shales and multicolored claystones, with emphasis on Deep Sea Drilling Project Site 530, southern Angola Basin. In: Initial Reports DSDP Vol 75, (Eds: W. W. Hay, J. C. Sibuet et al.) US Govt Printing Office, Washington, DC, p 819-844

Dean, W. E., Arthur, M. A. and Claypool, G. E. (1986) Depletion of ${ }^{13} \mathrm{C}$ in Cretaceous marine organic matter: source, diagenetic, or environmental signal? Mar. Geol. 70, 119-157

de Graciansky, P. C., Deroo, G., Herbin, J. P., Montadert, L., Müller, C., Schaaf, A. and Sigal, J. (1984) Ocean-wide stagnation episode in the Late Cretaceous Nature 308 , 346-349

Demaison, G. J. and Moore, G. T. (1980) Anoxic environments and oil source bed genesis Org. Geochem. 2, 9-31

Deroo, G., Herbin, J. P., Roucaché, J. and Tissot, B. (1980) Organic geochemistry of Cretaceous sediments at DSDP Holes 417D (Leg 51), 418A (Leg 52), and 418B (Leg 53) in the western North Atlantic. In: Initial Reports, DSDP, Vols 51, 52, 53, Pt 2: US Govt Printing Office, Washington, DC, p 737-745

Didyk, B. M., Simoneit, B. R. T., Brassell, S. C. and Eglinton, G. (1978) Geochemical indicators of palaeoenvironmental conditions of sedimentation Nature 272, 216-222

Dunham, K. W., Meyers, P. A. and Dunham, P. L. (1987) Organic geochemical comparison of Cretaceous black shales and adjacent strata from Deep Sea Drilling Project Site 603, outer Hatteras Rise, In: Initial Reports DSDP, Vol 93 (Eds J. E. van Hinte, S. W. Wise Jr et al.) US Govt. Printing Office, Washington, DC, p 1195-1210

Emeis, K.-C., Mycke, B., Richnow, H.-H., Spitzy, A. and Degens, E. T. (1987) Organic carbon and nitrogen, sediment composition, and clay mineralogy of Deep Sea Drilling Project Site 603, western Atlantic Ocean, In: Initial Reports, DSDP, Vol. 93 (Eds J. E. van Hinte, S. W. Wise Jr, et al.) US Govt. Printing Office, Washington, DC, p 1245-1256

Erdman, J. G. and Schorno, K. S. (1978) Geochemistry of carbon: Deep Sea Drilling Project Leg 44. In: Initial Reports DSDP, Vol. 44 (Eds W. E. Berison, R. E. Sheridan, et al.) US Govt. Printing Office, Washington, DC, p 605-615 
Habib, D. and Drugg, W. S. (1987) Palynology of Sites 603 and 605, Leg 93, Deep Sea Drilling Project, In: Initial Reports, DSDP, Vol 93 (Eds. J. E. van Hinte, S. W. Wise Jr, et al.) US Govt Printing Office, Washington, DC, p 751-775

Herbin, J. P., Masure, E., and Roucaché, J. (1987) Cretaceous formations from the lower continental rise off Cape Hatteras: Organic geochemistry, dinoflagellate cysts, and the Cenomanian/Turonian Boundary Event at Sites 603 (Leg 93) and 105 (Leg 11), In: Initial Reports, DSDP, Vol. 93 (Eds J. E. van Hinte, S. W. Wise Jr, et al.) US Govt Printing Office, Washington, DC, p 1139-1162

Jansa, L. F., Enos, P., Tucholke, B. E., Gradstein, F. M. and Sheridan, R. E. (1979) Mesozoic-Cenozoic sedimentary formations of the North American Basin. Western North Atlantic. In: Deep Drilling Results in the Atlantic Ocean: Continental Margins and Paleoenvironment (Eds M. Talwani, W. Hay and W. B. F. Ryan) American Geophysical Union, Washington, DC, $p$ 1-57

Jenkyns, H. D. (1980) Cretaceous anoxic events: from continents to oceans. J. Geol. Soc. London 137, 171-188

Joyce, R. M. and van Vleet, E. S. (1987) A geochemical study of organic matter rich Upper Cretaceous claystones from the lower continental rise off North America, Deep Sea Drilling Project Hole 603B, In: Initial Reports DSDP, Vol. 93 (Eds J. E. van Hinte, S. W. Wise Jr, et al.) US Govt, Printing Office, Washington, DC, p 1223-1230

Katz, B. J. (1987) Organic geochemical character and hydrocarbon source potential of selected black shales, Deep Sea Drilling Project Hole 603B, In: Initial Reports DSDP, Vol. 93 (Eds. J. E. van Hinte, S. W. Wise Jr, et al.) US Govt. Printing Office, Washington, DC, p 1177-1185

Katz, B. J. and Pheifer, R. N. (1982) Characteristics of Cretaceous organic matter in the Atlantic. In: Geology of Continental Margins, (Eds J. Watkins and C. Drake) AAPG Memoir, 34, Am. Assoc. Petrol. Geol. p 617-628

Meyers, P. A. (1987) Organic-carbon content of sediments and rocks from Deep Sea Drilling Project Sites 603, 604, and 605, western margin of the North Atlantic, In: Initial Reports DSDP, Vol. 93 (Eds J. E. van Hinte, S. W. Wise Jr, et al.) US Govt Printing Office, Washington, DC, p 1187-1194

Meyers, P. A., Leenheer, M. J., Kawka, O. E. and Trull, T. W. (1984) Enhanced preservation of marine-derived organic matter in Cenomanian black shales from the southern Angola Basin Nature, 312, 356-359

Müller, P. J. (1977) $\mathrm{C} / \mathrm{N}$ ratios in Pacific deep-sea sediments: Effects of inorganic ammonium and organic nitrogen compounds sorbed by clays. Geochim. Cosmochim. Acta 41. 765-776

Risatti, J. B., Rowland, S. J., Yon, D. and Maxwell, J. R. (1984) Stereochemical studies of acyclic isoprenoids - XII. Lipids of methanogenic bacteria and possible contributions to sediments Org. Geochem. 6, 93-104
Rullkötter, J., Mukhopadhyay, P. K. and Welte, D. H. (1987) Geochemistry and petrography of organic matter from Deep Sea Drilling Project Site 603, lower continental rise off Cape Hatteras, In: Initial Reports DSDP, Vol. 93 (Eds J. E. van Hinte, S. W. Wise Jr, et al.) US Govt. Printing Office, Washington, DC, $p$ 1163-1176

Schaefer, R. G. and Leythaeuser, D. (1987) Low-molecularweight hydrocarbons in sediments of Deep Sea Drilling Project Leg 93, Hole 603B, off the east coast of North America, In: Initial Reports DSDP, Vol. 93 (Eds. J. E. van Hinte, S. W. Wise Jr, et al.) US Govt Printing Office, Washington, DC, p 1237-1244

Stein, R. (1986) Organic carbon and sedimentation rate: Further evidence for anoxic deep-water conditions in the Cenomanian/Turonian Atlantic Ocean Mar. Geol. 72, 199-209

Stevenson, F. J. and Cheng, C.-N. (1972) Organic geochemistry of the Argentine Basin sediments: Carbon-nitrogen relationships and Quaternary correlations Geochim. Cosmochim. Acta 36, 653-671

Summerhayes, C. P. (1981) Organic facies of middle Cretaceous black shates in the deep North Atlantic AAPG Bull. 65, 2364-2380

Summerhayes, C. P. and Masran, T. C. (1983) Organic facies of Cretaceous and Jurassic sediments from Deep Sea Drilling Project Site 534 in the Blake-Bahama Basin, western North Atlantic. In: Initial Reports DSDP, Vol. 76, (Eds R. E. Sheridan, F. M. Gradstein, et al.) US Govt Printing Office, Washington, DC, p 469-480

Tissot, B. P., Demaison, G., Masson, P., Deteil, J. R. and Combaz, A. (1980) Paleoenvironment and petroleum potential of the mid-Cretaceous black shales in the Atlantic basins. AAPG Bull. 64, 2051-2063

van Hinte, J. E. and Leg 93 Shipboard Party (1987) Site 603, In: Initial Reports DSDP, Vol. 93 (Eds J. E. van Hinte, S. W. Wise $\mathrm{Jr}$, et al.) US Govt Printing Office, Washington, DC, p 25-276

Waples, D. W. (1983) Reappraisal of anoxia and organic richness, with emphasis on Cretaceous of North Atlantic. AAPG Bull. 67, p 963-978

Waples, D. W. and Sloan, J. R. (1980) Carbon and nitrogen diagenesis in deep sea sediments Geochim. Cosmochim. Acta. 44, 1463-1470

Whelan, J. K. and Burton, C. (1987) C1-C3 hydrocarbons in sediments from the lower continental rise, Deep Sea Drilling Project Site 603, In: Initial Reports DSDP, Vol. 93 (Eds J. E. van Hinte, S. W. Wise Jr, et al.) US Govt Printing Office, Washington, DC, $\mathrm{p}$ 1231-1236

Wise S. W., Jr and van Hinte, J. E. (1987) Mesozoic-Cenozoic depositional environments revealed by Deep Sea Drilling Project Leg 93 drilling on the continental rise off the eastern United States: Cruise summary, In: Initial Reports DSDP, Vol. 93 (Eds J. E. van Hinte, S. W. Wise Jr, et al.) US Govt Printing Office, Washington, DC, p 1367-1423 